\title{
Caracterización y conservación de la piedra usada en la Catedral de Granada, España
}

\section{Characterization and conservation of the stone used in the Cathedral of Granada, Spain}

R. VILLEGAS ${ }^{\star}$, L. MARTÍN ${ }^{\star}$, J.F. VALE ${ }^{\star \star}$ y M.A. BELLO ${ }^{\star \star \star}$

* Insto. Andaluz del Patrimonio Histórico (Sevilla); ** Dpto. Ingeniería Química y Ambiental / Univ. Sevilla;

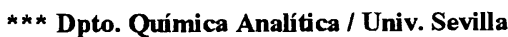

Fecha de recepción: 26-IX-95

ESPAÑA

\section{RESUMEN}

Este articulo recoge un estudio llevado a cabo sobre la Catedral de Granada que incluye la determinación de los indicadores, factores y mecanismos de deterioro. Asimismo se ha realizado una completa caracterización fisica y química del material alterado del edificio e inalterado de cantera. Se han probado ocho productos comerciales aplicados al principal tipo de piedra existente en el monumento, incluyendo la realización de dos ensayos de alteración acelerada (cristalización de sales y ataque químico con atmósfera de $\mathrm{SO}_{2}$ ). Como punto final se recogen algunas recomendaciones de cara a una posible intervención.

\section{SUMMARY}

This paper summarizes a study carried out on the Granada Cathedral which includes studies of indicators, factors and mechanisms of deterioration. A complete chemical and physical characterization of altered and unaltered material from the quarries and the building has been made. Eight commercial treatment products have been tested on the main stone-type used in the monument, including two accelerated weathering tests (salt crystallization and $\mathrm{SO}_{2}$ chemical attack). Some conservation proposals have been made.

\section{INTRODUCCIÓN}

La Catedral de Granada (1506-1783) es un conjunto monumental formado por la Catedral, la Capilla Real y la iglesia del Sagrario. Está situada en el centro de la ciudad, con una alta densidad de tráfico rodado en los alrededores; este hecho y las extremas condiciones climáticas son las causas del alto grado de alteración de las piedras usadas en el exterior de la Catedral. Otros factores de alteración en determinadas zonas del edificio son la humedad del subsuelo y la sismicidad.

Para la construcción de la Catedral se usaron básicamente tres tipos de piedra, de las canteras de Santa Pudia, Sierra Elvira y Alfácar (todas en la provincia de Granada). De ellas la más abundante es la

\section{INTRODUCTION}

The Cathedral of Granada (1506-1783) is a monumental whole formed by the Cathedral, the Royal Chapel and the Shrine. It is located at the centre of the city, with high traffic density in the surroundings; this fact and the extreme climatic conditions cause the high alteration degree of the stones used in the exterior zones of the Cathedral. Other factors of weathering on some zones of the monument are subsoil humidity and seismicity.

For the construction of the Cathedral of Granada basically three stone types were used from Santa Pudia, Sierra Elvira and Alfácar quarries (all from the province of Granada). The most abundant stone is the 
primera, una caliza bioesparítica de color amarillento y textura heterogranuda; se han podido encontrar dos variedades diferentes en el monumento con diferente grado de compacidad, ambas muy porosas, siendo la más utilizada la más porosa, por lo que este trabajo se ha centrado sobre ella.

Los factores de alteración que actúan sobre el monumento originan numerosas manifestaciones de deterioro que han sido descritas ampliamente (1). Entre ellos los indicadores más importantes que aparecen en la piedra de Santa Pudia son los relacionados con el ataque químico y con procesos de cristalización.

La ciudad de Granada, a $664 \mathrm{~m}$ sobre el nivel del mar, se ha incluido en la región climática continental, subregión continental extrema (2), la cual se caracteriza por inviernos fríos y veranos muy cálidos; el gran número de días al año con temperaturas por debajo de $0^{\circ} \mathrm{C}$ y las grandes oscilaciones térmicas diarias -se registran diferencias de hasta $30^{\circ} \mathrm{C}$ en un día- son fenómenos importantes. La humedad relativa media oscila entre el $30 \%$ en julio y el $90 \%$ en enero; en el mismo día sa han observado oscilaciones de un $40 \%$ en la misma (3).

La Catedral se construyó en el antiguo lecho del río Darro, lo cual determina la existencia de un alto nivel freático en el subsuelo de la Catedral; todavía hoy subsisten antiguos pozos. Los frecuentes e intensos riegos de limpieza pública contribuyen a la humedad de las zonas bajas del monumento.

Los niveles de contaminación atmosférica en los alrededores son altos. En las fachadas del monumento se han registrado valores mayores de $50 \mu \mathrm{g} / \mathrm{cm}^{3}$ de $\mathrm{SO}_{2}$ y $54-315 \mathrm{mg} / \mathrm{m}^{2}$ día de partículas sedimentables (fracciones soluble - no soluble). Estos datos indican que existe la posibilidad de ataque químico a la piedra caliza.

En este trabajo, se ha caracterizado el principal tipo de piedra usado en el monumento y se ha evaluado el comportamiento de algunos de los productos de tratamiento más empleados, midiendo la variación de las propiedades más representativas de las muestras tratadas, antes y después de someterlas a alteración por cristalización de sales y por ataque químico.

\section{EXPERIMENTAL}

\subsection{Muestras}

Se han tomado más de 100 muestras de la zona exterior de la Catedral. El muestreo se ha realizado teniendo en first, a biosparitic limestone of yellowish colour and heterograined texture from Santa Pudia (farmhouse) quarry, Escúzar (Granada); two varieties with different compacity degree were employed, being both very porous; however, the most abundant type in the monument is the more compact one, and for this reason, this study focuses on this variety.

The alteration factors which actuate on the monument cause numerous alteration manifestations which have been profusely described (1). However, the most important indicators of alteration which appear on the Santa Pudia stones are those associated to chemical attack and crystallization processes.

The city of Granada, $664 m$ above sea level, has been included in the Spanish climatic continental region, continental extreme subregion (2), which is characterized by cold winters and very warm summers; the high number of days per year with temperatures lower than $0^{\circ} \mathrm{C}$ and the great thermic oscillations are important, having been registered oscillations of $30^{\circ} \mathrm{C}$ in a day. The average relative humidity values oscillate between $30 \%$ in July and 90\% in January; on the same day, oscillations of $40 \%$ in the RH have been registered (3).

The Cathedral was built on the ancient riverbed of the Darro river, which implies a high humidity level in the Cathedral subsoil; nowadays, ancient pit water subsists. The frequent and intense irrigations by public services for neatness contribute to the dampness of the lower zones of the monument.

The levels of environmental pollution in the surroundings are high. On the monument facades, values greater than $50 \mu \mathrm{g} / \mathrm{m}^{3}$ of $\mathrm{SO}_{2}$ and $54-315 \mathrm{mg} / \mathrm{m}^{2}$ day of sedimentable particles (soluble + nonsoluble fractions) have been registered. These data indicate the possibility of chemical attack of the limestone.

In this work, the main stone type used in this monument has been characterized and the behaviour of some of . the main treatment products tested by measuring the variation of various important properties of the treated stones before and after being submitted to salt crystallization and chemical attack accelerated alteration processes.

\section{EXPERIMENTAL}

\subsection{Sampling}

More than 100 samples of the stones used in the exterior zones of the Cathedral were taken. Sampling 
cuenta las diferentes piedras usadas, su localización en el monumento, el tipo y grado de alteración y todos los factores que pueden influir en el grado de alteración de la piedra.

Para los ensayos que requieren grandes cantidades de material se han empleado probetas de cantera.

\subsection{Métodos}

Para la determinación de la composición mayoritaria de la piedra se ha seguido la metodología propuesta por Berzosa y Martín (4-6).

La determinación de la resistencia a la compresión y a la flexión (7) se ha medido en una prensa universal Ibertest DF-12000, usando probetas de $4 \times 4 \times 4 \mathrm{~cm}$ y de $16 \times 4 \times 4 \mathrm{~cm}$, respectivamente.

La dureza superficial se ha medido con un equipo Hoyton 1005 con una bola de $5 \mathrm{~mm}$ de diámetro, aplicando una precarga de $10 \mathrm{~kg}$ y una carga final de $30 \mathrm{~kg}$. La dureza superficial se obtiene como función inversa de la profundidad de penetración de la bola.

El grado de compacidad se ha determinado con un medidor de ultrasonidos Controls E46.

La difracción de Rayos $X$ se ha realizado con un difractómetro Philips PW-1710, usando radiación $\mathrm{CuK} \alpha$ y filtro de $\mathrm{Ni}$.

La porosimetria de inyección de mercurio se ha realizado con un equipo Micromeritics 9320, usando trozos de 2-3 mm extraidos de la zona externa de las muestras (tratadas y no tratadas). El rango de tamaños de poros cubierto es aproximadamente 0,3-200 $\mu \mathrm{m}$.

Los parámetros hídricos más significativos se han determinado siguiendo las recomendaciones RILEM (8). Se han utilizado probetas cúbicas de $5 \mathrm{~cm}$ de arista.

Para el ensayo de alteración acelerada por ataque con atmósfera contaminada con $\mathrm{SO}_{2}$ se ha utilizado una cámara construida a medida $(9,10)$.

\section{CARACTERIZACIÓN DE LA PIEDRA}

\subsection{Material inalterado}

La Tabla 1 muestra la composición química mayoritaria de las dos variedades de la piedra de Santa Pudia; como puede observarse, ambos materiales tienen una composición química muy similar, presentando sólo diferencias texturales (11). has been carried out taking into account the different stones used, their location in the monument, the alteration type and degree and all the factors which determine the present state of conservation of the stony materials.

For the studies which require unaltered material, samples from the quarries were obtained.

\subsection{Methods}

For the determination of the major composition of the stones, Berzosa and Martín methodology (4-6) was employed.

The determination of the compressive and flexure strengths (7) were carried out in an Ibertest DF-12000 universal test press, using specimens of $4 \times 4 \times 4 \mathrm{~cm}$ and $16 \times 4 \times 4 \mathrm{~cm}$, respectively.

The surface hardness was tested with a Hoyton 1005 Hardness Tester with a $5 \mathrm{~mm}$ diameter ball and applying a preload of $10 \mathrm{~kg}$ and a total load of $30 \mathrm{~kg}$. Hardness was obtained as inverse function of the ball penetration depth.

The compacity degree was tested with a Controls E46 ultrasonic tester.

$X$-ray powder diffraction patterns were obtained with a Philips PW-1710 diffractometer using CuK $\alpha$ radiation and Ni filter.

Mercury intrusion porosimetry measurements were performed with a Micromeritics 9320 porosimeter by using pieces of 2-3 $\mathrm{mm}$ obtained from the external zone of the samples (treated and untreated). The pore size range covered was approximately 0.3-200 $\mu \mathrm{m}$.

The most significant hygric parameters were determined according to RILEM proposal (8). ('ubic specimens of $5 \mathrm{~cm}$ edge have been employed.

For the chemical accelerated weathering test with $\mathrm{SO}_{2}$ polluted atmosphere, a home-made simulation chamber was used $(9,10)$.

\section{STONE CHARACTERIZATION}

\subsection{Unaltered material}

Table 1 shows the major chemical composition of the two varieties of Santa Pudia stones; as can be observed, both materials have a very similar chemical composition, presenting only textural differences (11). 
La distribución de tamaño de poros de dicha piedra se representa en la Figura 1. En ella aparecen tres curvas correspondientes a muestras con porosidad total diferente, y puede observarse que la distribución porosimétrica es muy similar, independientemente de la cantidad total de poros.

En la Tabla 2 se recogen los principales parámetros hídricos del material.

En la Tabla 3 aparecen los valores de resistencia a la flexión y la resistencia a la compresión.

El grado de compacidad del material se ha evaluado midiendo la velocidad de ultrasonido, que da valores de $3.500-3.900 \mathrm{~m} \mathrm{~s}^{-1}$ para muestras inalteradas.
The pore size distribution of the Santa Pudia stone is represented on Figure 1. In this Figure, three curves corresponding to samples with different total porosity appear, and it can be seen that the distribution of pore sizes is very similar, independently of the total quantity of pores.

In Table 2, the main hygric parameters for the Santa Pudia stones can be observed.

On Table 3 values for flexure strength and compressive strength are given.

The compacity degree of the materials was checked by ultrasonic testing; values of 3500-3900 $\mathrm{m} \mathrm{s}^{1}$ were obtained for the unaltered Santa Pudia materials.

\section{TABLA 1 (TABLE 1)}

Composición química (\%) de elementos mayoritarios de los dos tipos de piedra de Santa Pudia, compacta (SPC) y de baja compacidad (SP) Major chemical composition (\%) of the two types of Santa Pudia stone, compact (SPC) and of low compacity (SP)

\begin{tabular}{|c|c|c|c|c|}
\hline \multirow{2}{*}{$\begin{array}{l}\text { TIPO DE PIEDRA } \\
\text { (TYPE OF STONE) }\end{array}$} & \multicolumn{2}{|c|}{ SPC } & \multicolumn{2}{|c|}{ SP } \\
\hline & $\begin{array}{c}\text { Media } \\
\text { (Average) }\end{array}$ & $\begin{array}{l}\text { Intervalo } \\
\text { (Interval) }\end{array}$ & $\begin{array}{c}\text { Media } \\
\text { (Average) }\end{array}$ & $\begin{array}{l}\text { Intervalo } \\
\text { (Interval) }\end{array}$ \\
\hline $\begin{array}{l}\text { Pérdida por calcinación } \\
\text { (Ignition loss) }\end{array}$ & 42,23 & $41,8-42,8$ & 43,31 & $43,0-43,6$ \\
\hline $\mathrm{SiO}_{2}$ & 2,39 & $2,1-3,1$ & 1,26 & $0,5-1,9$ \\
\hline $\mathrm{Al}_{2} \mathrm{O}_{3}$ & 0,38 & $0,3-0,5$ & 0,15 & $0,1-0,2$ \\
\hline $\mathrm{Fe}_{2} \mathrm{O}_{3}$ & 0,36 & $0,3-0,4$ & 0,26 & $0,2-0,4$ \\
\hline $\mathrm{CaO}$ & 53,2 & $53,0-53,3$ & 53,9 & $53,1-54,6$ \\
\hline $\mathrm{MgO}$ & 0,41 & $0,3-0,5$ & 0,35 & $0,3-0,4$ \\
\hline $\mathrm{Na}_{2} \mathrm{O}$ & 0,77 & $0,7-0,9$ & 0,75 & $0,6-0,9$ \\
\hline $\mathrm{K}_{2} \mathrm{O}$ & 0,18 & $0,1-0,3$ & 0,10 & $0,05-0,2$ \\
\hline $\mathrm{SO}_{3}$ & 0,26 & $0,2-0,3$ & 0,28 & $0,2-0,4$ \\
\hline Total & 100,17 & & 100,36 & \\
\hline
\end{tabular}

TABLA 2 (TABLE 2)

Parámetros hídricos de la piedra de Santa Pudia compacta sin alterar (Hygric parameters for Santa Pudia compact unaltered material)

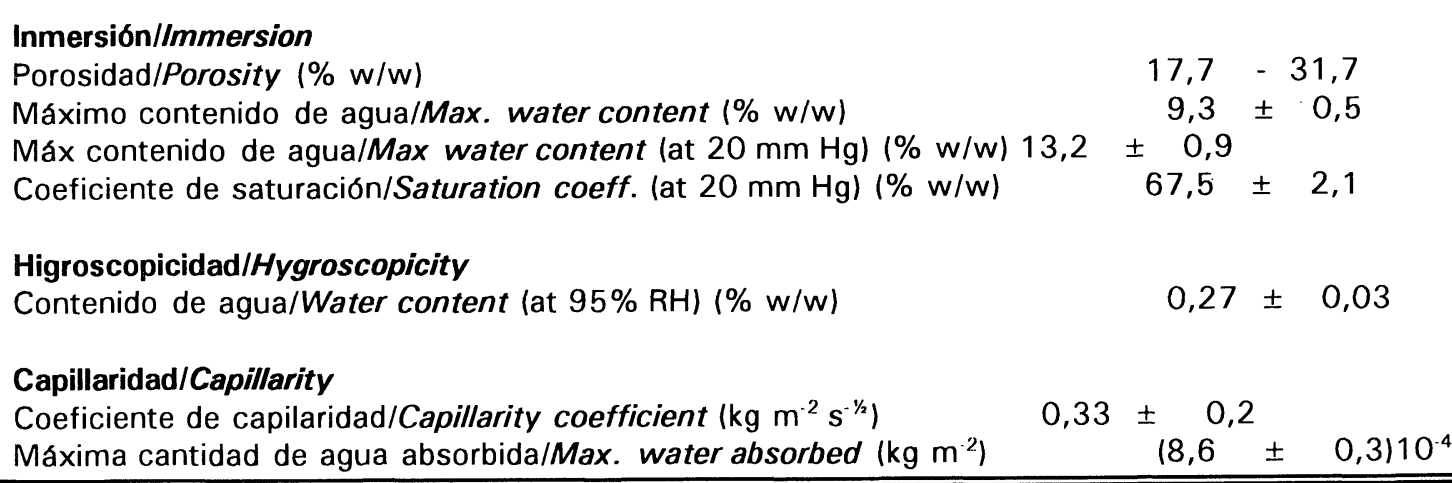


TABLA 3 (TABLE 3)

Propiedades mecánicas de la piedra de Santa Pudia sin tratar (Mechanical properties of untreated Santa Pudia stone)

\begin{tabular}{||l|c|c||}
\hline & $\begin{array}{c}\text { Resistencia flexión } \\
\text { (Flexure strengh) }\end{array}$ & $\begin{array}{c}\text { Resistencia compresión } \\
\text { (Compressive strengh) }\end{array}$ \\
\hline Inalterada/Unaltered & $38-40 \mathrm{kp} \mathrm{m}^{-2}$ & $120-186 \mathrm{kp} \mathrm{cm}^{-2}$ \\
\hline Alterada/Weathered & $24-25 \mathrm{kp} \mathrm{cm}^{-2}$ & $105-159 \mathrm{kp} \mathrm{cm}^{-2}$ \\
\hline
\end{tabular}

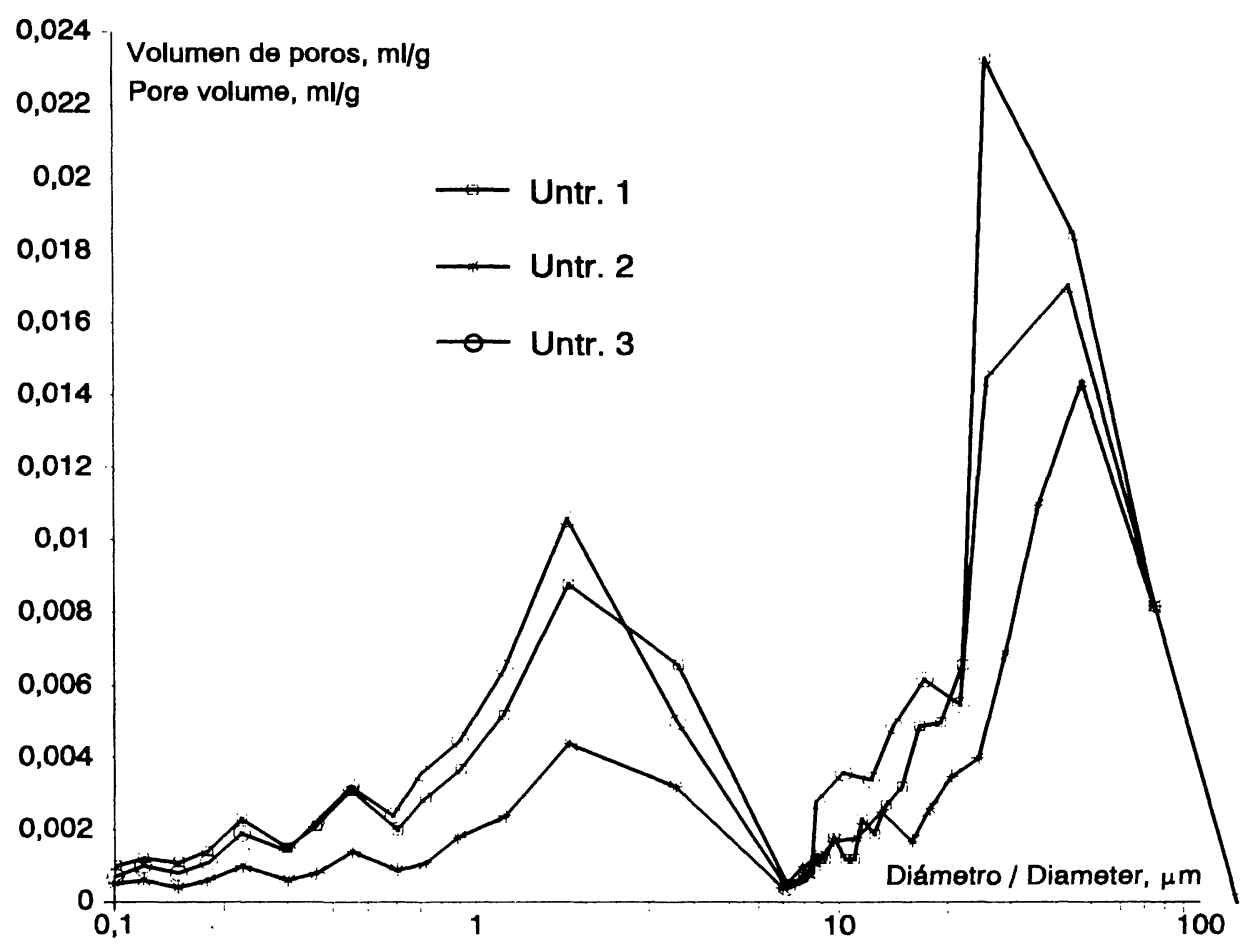

Fig. 1.- Distribución de tamaños de poro de muestras de cantera de Santa Pudia.

Fig. 1.- Pore size distribution for Santa Pudia quarry samples.

\subsection{Material del edificio}

Los factores, indicadores y mecanismos del alteración que aparecen en la Catedral, se han descrito previamente $(1,12)$

Pueden hacerse algunas consideraciones sobre las variaciones de composición química de los materiales del edifício. Sólo se aprecia un cambio apreciable en la composición química mayoritaria en las muestras en las que ha tenido lugar un ataque químico; se produce un gran incremento en la proporción de $\mathrm{SO}_{3}$ (son frecuentes valores del orden del $25 \%$ ), que está presente como yeso $\left(\mathrm{CaSO}_{4} \cdot \mathrm{H}_{2} \mathrm{O}\right)$ La Figura 2 muestra dos difractogramas de Rayos X correspondientes a la superficie y el interior de una muestra alterada.

\subsection{Materials from the building}

The factors, indicators and mechanisms of deterioration present in the Cathedral of Granada have been previously described $(1,12)$.

Some considerations must be made about the variations on the chemical composition of the building materials. An appreciable change on the major composition occurs only in the materials where a chemical attack has taken place, with great increases on the $\mathrm{SO}_{3}$ percentage (values of approximately $25 \%$ are frequent), which is present as gypsum (CaSO ${ }_{4}$ $2 \mathrm{H}_{2} \mathrm{O}$ ). Figure 2 shows two typical X-Ray diffractograms corresponding to the surface and interior of a weathered building sample. 
El análisis de la fracción soluble revela sólo contenidos importantes de sulfato y calcio, lo que indica que sólo la cristalización-solubilización de yeso podría producir daños. Sin embargo, algunas muestras, fundamentalmente de la fachada principal, contienen importantes cantidades de fosfatos procedentes de excrementos de paloma (la acción de las palomas se ha descrito ampliamente).

Los procesos más importantes de deterioro químico tienen lugar en los elementos ornamentales situados cerca de calles con tráfico denso, donde se registran los niveles de $\mathrm{SO}_{2}$ más elevados. Las zonas bajas de las cornisas muestran disgregaciones graves debido al paso de agua que origina ciclos de humedad/secado, siendo, además, zonas donde se ve favorecido el ataque químico gracias al alto nivel de humedad.
The water-soluble fraction analysis reveals only important contents of sulphate and calcium which indicate that only gypsum solubilization-recrystallization could produce, in most of the cases, salt damages. However, some samples, fundamentally in the main facade, show important quantities of phosphate due to the pigeon excreta; all the damages for pigeon actions have been profusely described by numerous authors.

The most important chemical deterioration processes occur on ornamental elements located basically near the streets with dense traffic, where the greatest $\mathrm{SO}_{2}$ levels were registered. The lower zones of the cornices show important grain dissagregation of the stone due to the water percolation which gives origin to wetting/drying cycles and, due to the high humidity levels, those are zones of preferential chemical attack.

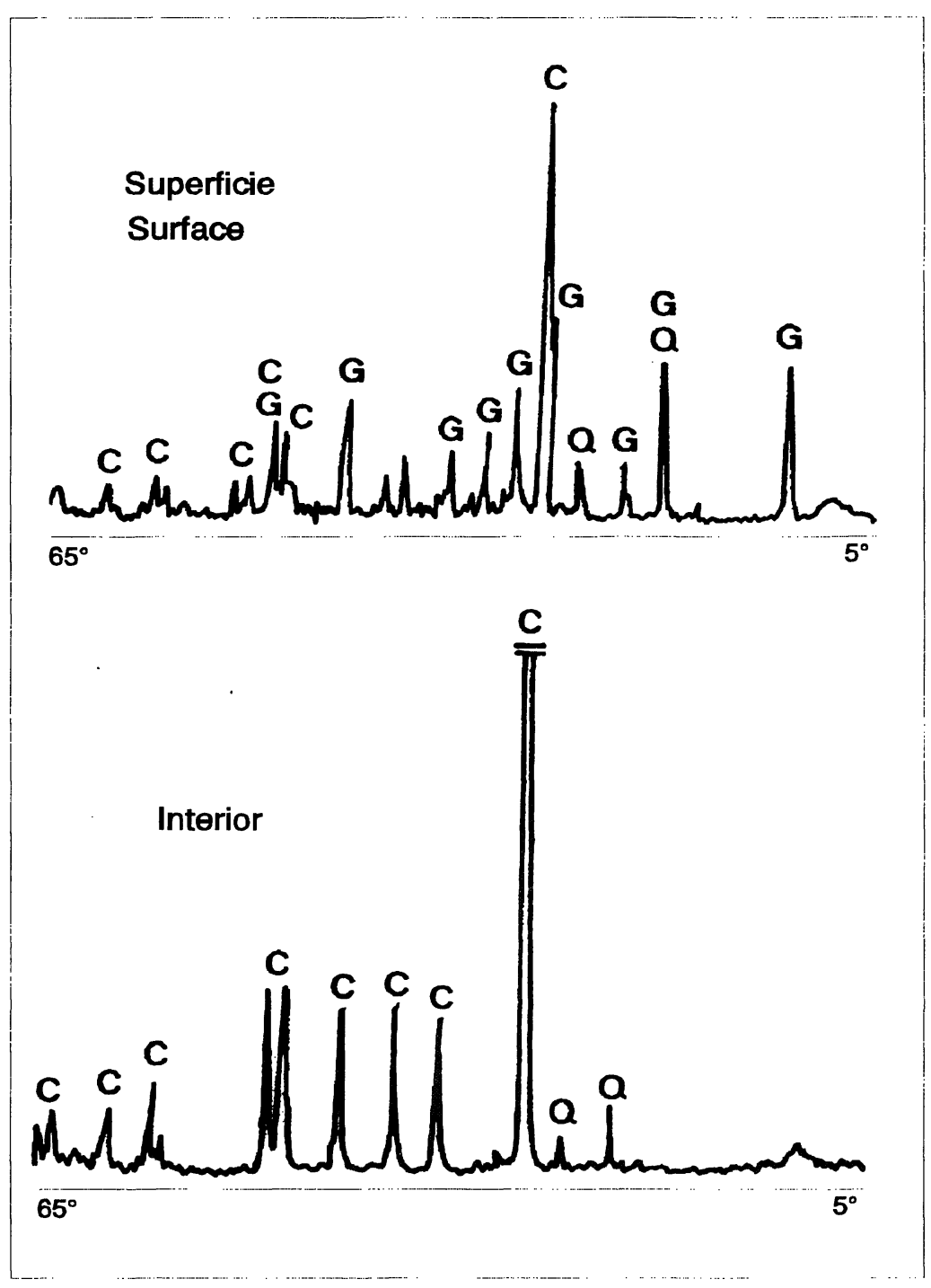

Fig. 2.- Difractogramas de rayos $\mathrm{X}$ de una muestra con alteración química superficial.

Fig. 2.- X-ray diffractograms for a building sample with chemical surface deterioration.
C: Calcita/Calcite
Q: Cuarzo/Quartz
G: Yeso/Gypsum 
En algunos casos tiene lugar un cambio considerable en la composición microquímica de la superficie; así, se aprecia un generalizado incremento de metales como $\mathrm{Fe}$, $\mathrm{Mn}, \mathrm{Cu}, \mathrm{Zn}$ y $\mathrm{Pb}$, cuyo papel en la oxidación catalítica del $\mathrm{SO}_{2}$ y el posterior ataque químico de la piedra se ha descrito ampliamente (13-15).

Algunas propiedades mecánicas del material alterado del monumento se recogen en la Tabla 3 , junto con las del material de cantera; se puede observar que el proceso de alteración sufrido causa una considerable disminución de las propiedades mecánicas del material.

\section{PRODUCTOS DE TRATAMIENTO}

\subsection{Tipos de productos}

En este trabajo se han estudiado ocho productos comerciales de tratamiento, seis de tipo organosilícico: Consolidante de piedra $\mathrm{OH}$ (silicato de etilo), Tegovakon $\mathrm{V}$ (silicato de etilo), Hidrófugo de silicona BS28 (organosilícico), $290 \mathrm{~L}$ (organosiloxano oligómero), Tegosivin HL 100 (organosilícico monómero), y Agente Impregnante Baysilone LV (resina de silicona); uno de tipo acrilsilicónico: ARD 55.050 (resina acrilsilicónica) y un producto acrílico: Paraloid B72 (copolímero de metilacrilato y etilmetacrilato).

Con respecto a su efecto, pueden clasificarse como sigue:

*Consolidantes: Consolidante $\mathrm{OH}$ y Tegovakon $\mathrm{V}$

*Consolidantes e hidrófugos: Paraloid B72 y ARD 55.050

*Hidrófugos: 290 L, Tegosivin HL 100 y Baysilone LV

*Hidrófugo y oleófugo: BS28

\subsection{Aplicación de los productos a las muestras de piedra}

Para todos los ensayos se han usado muestras cúbicas de $5 \mathrm{~cm}$ de arista. Antes de aplicar los tratamientos las muestras se han limpiado, humedecido y secado al aire hasta alcanzar un contenido de humedad de 0-2 g; este procedimiento reproduce el estado de la piedra en el edificio y favorece la polimerización de los productos organosilícicos (16-18).

Con cada producto se han tratado doce muestras por inmersión durante 10 minutos, para alcanzar una penetración uniforme por todas las caras. Dada la alta porosidad de la piedra este tiempo es suficiente para lograr una total impregnación de las muestras; sólo Paraloid no penetra por completo, alcanzando una profundidad de unos $6 \mathrm{~mm}$; este hecho puede deberse a
In some cases, very important changes on the microchemical composition occur on the stone surface; so. a generalized increase of metals like $\mathrm{Fe}, \mathrm{Mn}, \mathrm{Cu}, \mathrm{Zn}$ and $\mathrm{Pb}$ was confirmed, and the role of some of these metals on the catalytic $\mathrm{SO}_{2}$ oxidation and the later chemical attack on the stone have been fully described (13-15).

Some mechanical properties of weathered material from the monument appear on Table 3, as well as those from quarry samples; it can be concluded that the weathering processes cause a notable decrease on the mechanical properties of these materials.

\section{TREATMENT PRODUCTS}

\subsection{Types of products}

For this study, eight known commercial products of conservation were tested, six of organosilicic type: Stone Strengthener OII (ethylsilicate), Tegovakon V (ethylsilicate), Silicone Masonry Water Repellent BS28 (organosilicic), 290L (oligomeric organosiloxane), Tegosivin IIL100 (monomeric organosilicic) and Baysilone Impregnating Agent LV (silicone resin); one of acrylsiliconic type: ARI) 55.050 (acrylsiliconic resin) and one acrylic product: Paraloid B72 (copolymer of methylacrylate and ethylmethacrylate).

With respect to their effect on the stone, they can be classified as:

*Consolidants: Strengthener $O H I$ and Tegovakon $V$

*(onsolidants + water repellents: Paraloid $B 72$ and ARI) 55.050

*Water repellents: 290L, Tegosivin HL100 and Baysilone L V

*Water and oil repellent: $B S 28$

\subsection{Application of the products to the stone samples}

Cubic samples of $5 \mathrm{~cm}$ edge were used for all the tests carried out. Before applying the products, the samples were cleaned, wetted and left in the air to dry until the water content was 0-2 $\mathrm{g}$; this procedure reproduces the state of the stone in the building and favours the polymerization of organosilicic products (16-18).

For each product, twelve samples were treated by ten minutes immersion in order to reach an uniform penetration on all faces. Due to the high stone porosity, this time is enough to achieve a total impregnation of the samples; only Paraloid does not penetrate completely, with a penetration depth of only $6 \mathrm{~mm}$; this fact can be due to the high viscosity of the 
la alta viscosidad de la solución y a la alta volatilidad del disolvente usado. La Tabla 4 muestra las diluciones y los disolventes empleados para preparar los productos para su aplicación.

Las probetas se han pesado periódicamente para seguir el proceso de secado/polimerización, que está determinado por la evaporación del disolvente y la polimerización del compuesto activo (si es un monómero).

El consumo de producto se calcula a partir del volumen absorbido por las probetas durante la impregnación.

La Tabla 5 muestra diversas características relacionadas con la impregnación de las muestras tratadas. solution and high volatility of the solvent used. Table 4 shows the dilutions and solvents used to prepare the products for the application.

The samples were periodically weighed with the aim to follow the drying/polymerization process, which is affected by the solvent evaporation and the polymerization of active compound (if it's a monomer).

The product consumption was calculated according to the volume absorbed by the samples during the impregnation.

Table 5 shows several characteristics related to impregnation of the treated samples.

\section{TABLA 4 (TABLE 4)}

Disolventes y disoluciones utilizadas para los productos aplicados (Solvents and disolutions used for the products applied).

\begin{tabular}{||ll||}
\hline PRODUCTO (PRODUCT) & DILUCION (DILUTION) \\
\hline Consolidante/Strengthener (OH) & Preparado para uso/Ready to use \\
Tegovakon V (TV) & Preparado para uso/Ready to use \\
BS28 & $5 \%(\mathrm{v} / \mathrm{v})$ con xileno/with xylene \\
$290 L$ & $1: 14(\mathrm{v} / \mathrm{v})$ con xileno/with xylene \\
Tegosivin HL 100 (TG) & $10 \%(\mathrm{v} / \mathrm{v})$ con xileno/with xylene \\
Baysilone LV (BY) & $5 \%(\mathrm{v} / \mathrm{v})$ con bencina/with benzine \\
ARD 55.050 (ARD) & Preparado para uso/Ready to use \\
Paraloid B72 (PA) & $10 \%(\mathrm{v} / \mathrm{v})$ con/with $1,1,1$-tricloroetano/trichloroeth \\
\hline
\end{tabular}

TABLA 5 (TABLE 5)

Características relacionadas con la impregnación (Characteristics related to impregnation)

\begin{tabular}{|c|c|c|c|c|c|c|}
\hline \multirow[b]{2}{*}{$\begin{array}{c}\text { PRODUCTO DE } \\
\text { TRATAMIENTO } \\
\text { (TREATMENT } \\
\text { PRODUCT) }\end{array}$} & \multicolumn{6}{|c|}{ PROPIEDADES (PROPERTIES) } \\
\hline & $\begin{array}{c}\text { Consumo de } \\
\text { Producto } \\
\text { Product } \\
\text { consumption } \\
\left(1 \mathrm{~m}^{-2}\right)\end{array}$ & $\begin{array}{l}\text { Tiempo de } \\
\text { secado } \\
\text { Drying } \\
\text { time } \\
\text { (h) }\end{array}$ & $\begin{array}{l}\text { Profundidad de } \\
\text { penetración } \\
\text { Depth of } \\
\text { penetration } \\
(\mathrm{mm})\end{array}$ & $\begin{array}{l}\text { Incremento } \\
\text { de peso } \\
\text { Weight } \\
\text { increase } \\
(\%)\end{array}$ & $\begin{array}{c}\text { Disminución } \\
\text { de porosidad } \\
\text { Porosity } \\
\text { decrease } \\
(\% \Delta)\end{array}$ & $\begin{array}{c}\text { Velocidad de } \\
\text { ultrasonidos } \\
\text { Ultrasonic } \\
\text { velocity" } \\
\left(\mathrm{ms}^{-1}\right)\end{array}$ \\
\hline Cons. OH & 1,35 & 100 & Total & $2,41 \pm 0,35$ & $3,55 \pm 0,52$ & $3795 \pm 250$ \\
\hline Tegovakon $\mathrm{V}$ & 1,75 & 200 & Total & $3,14 \pm 0,38$ & $2,62 \pm 0,29$ & $3738 \pm 272$ \\
\hline ARD 55.050 & 1,60 & 100 & Total & $0,93 \pm 0,12$ & $0,93 \pm 0,29$ & $3532 \pm 20$ \\
\hline Paraloid B72 & 1,57 & 50 & 6 & $0,93 \pm 0,16$ & $0,73 \pm 0,60$ & $3447 \pm 84$ \\
\hline $290 \mathrm{~L}$ & 1,05 & 150 & Total & $0,39 \pm 0,06$ & $1,15 \pm 0,72$ & $3526 \pm 280$ \\
\hline BS28 & 1,13 & 150 & Total & $0,46 \pm 0,05$ & $1,29 \pm 0,64$ & $3699 \pm 295$ \\
\hline Baysilone & 1,07 & 500 & Total & $0,44 \pm 0,06$ & $0,72 \pm 0,45$ & $3415 \pm 180$ \\
\hline Tegosivin HL100 & 1,54 & 200 & Total & $0,93 \pm 0,15$ & $1,45 \pm 0,45$ & $3513 \pm 246$ \\
\hline
\end{tabular}

" Piedra sin tratar/Untreated stone: $3415 \pm 283$ 
La velocidad de ultrasonidos se ha medido en tres muestras tratadas con cada producto (cinco probetas sin tratar), realizando tres medicias perpendiculares en cada probeta, calculando la media de estos nueve valores (quince para la piedra sin tratar). Se puede observar que los consolidantes organosilícicos producen un incremento significativo de esta característica, debido al hecho de que los incrementos de peso que producen son los más altos.

Con respecto a los cambios en la distribución de tamaños de poros, la Figura 3 muestra la distribución porosimétrica para la piedra tratada. La Tabla 6 contiene los principales datos proporcionados por el porosímetro de mercurio. En ambas, cada muestra tratada se compara con la muestra sin tratar, cuya porosidad total es más parecida, para hacer más evidentes los cambios debidos al tratamiento. La disminución de porosidad total es mayor para los consolidantes organosilícicos. En la muestra tratada con Paraloid aparece mayor diferencia entre la porosidad al agua y al $\mathrm{Hg}$, debido, probablemente, a la acumulación de producto en la superficie. El diámetro de poro medio aumenta con todos los tratamientos, lo cual indica que los poros más afectados son aquéllos por debajo de $10 \mu \mathrm{m}$. Por lo que respecta a los cambios en la porometría, pueden observarse dos comportamientos diferentes. Entre los productos hidrófugos, algunos (Paraloid B72, Tegosivin HL 100, 290L y ARD) producen un marcado descenso en el volumen de poros entre 0,1 y $10 \mu \mathrm{m}$ y un ligero descenso en el volumen de poros por encima de $10 \mu \mathrm{m}$ (Figura 3). Estos tratamientos no tienen un buen comportamiento en el ensayo de cristalización de sales. Los otros dos tratamientos hidrófugos (Baysilone y BS 28) producen una menor disminución de porosidad y su comportamiento en el ensayo de cristalización de sales es mucho mejor.

Los consolidantes organosilícicos también dan lugar a una disminución acusada en la porosidad entre 0,1 y $10 \mu \mathrm{m}$, pero, debido a su carencia de propiedades hidrófugas, sus resultados en el ensayo de cristalización de sales no son comparables.

\subsection{Propiedades hídricas}

Se han medido varias propiedades relacionadas con la absorción de agua siguiendo las propuestas RILEM (8). La Tabla 7 muestra los principales resultados obtenidos con 10 probetas tratadas con cada producto.

La absorción capilar disminuye considerablemente en las muestras tratadas con hidrófugos, mientras que la disminución es muy pequeña en las muestras tratadas con Tegovakon $\mathrm{V}$, e intermedia en las tratadas con Consolidante $\mathrm{OH}$.
Ultrasonic velocity has been measured on three samples treated with each product (five samples untreated). carrying out three perpendicular measurements on each sample, calculating the average of these nine values (fifteen for untreated). It can be seen that the organosilicic consolidants give a noticeable increase of this characteristic, due to the fact that the weight increments that they produce are the highest.

With respect to the changes in the pore size distribution, Figure 3 shows the typical pore size distribution for the Santa Pudia materials treated with the selected products. Table 6 shows the main textural data obtained from mercury intrusion porosimetry. Both on Table 6 and on Figure 3, each treated sample is compared with the untreated one that has a more similar total porosity, in order to make changes due to the application of treatments evident. From the values on Table 6, several considerations could be made. The decrease in the porosity due to the treatments is higher for the organosilicic consolidants. Apart from these two cases, on the sample treated with Paraloid (very superficial impregnation) is where the difference between $\mathrm{Hg}$ porosity and water porosity exists, due, probably, to the accumulation of product on the surface. The median pore diameter increases with all the treatments, fact that indicates that the more affected pores are those below $10 \mu \mathrm{m}$. For what respects to these changes, two different behaviours can be observed. Among those products which have hydrophobic properties, some of them (Paraloid B72, Tegosivin HL100, $290 L$ and ARD) cause a marked decrease in the pores between 0,1 and $10 \mu \mathrm{m}$, and a slight decrease in the pores over $10 \mu \mathrm{m}$ (Figure 3). These treatments do not have a good behaviour on the salt crystallization test. The other two hydrophobic treatments (Baysilone and BS28) produce a much lower decrease in the porosity and their behaviour on the salt crystallization test is much better.

The organosilicic consolidants also give rise to a porosity decrease in pore sizes between 0,1 and $10 \mu \mathrm{m}$, but, due to their lack of hydrophobic properties, their results on the crystallization test are not comparable.

\subsection{Hygric properties}

Several properties related to water were measured according to the RILEM proposal (8). Table 7 shows the main results obtained from ten cubic samples treated with each product.

The capillarity absorption becomes very low on the samples treated with water repellent products, while it decreases slightly on samples treated with Tegovakon $\mathrm{V}$ and notably on those treated with Strengthener $\mathrm{OH}$ (both only consolidants). 

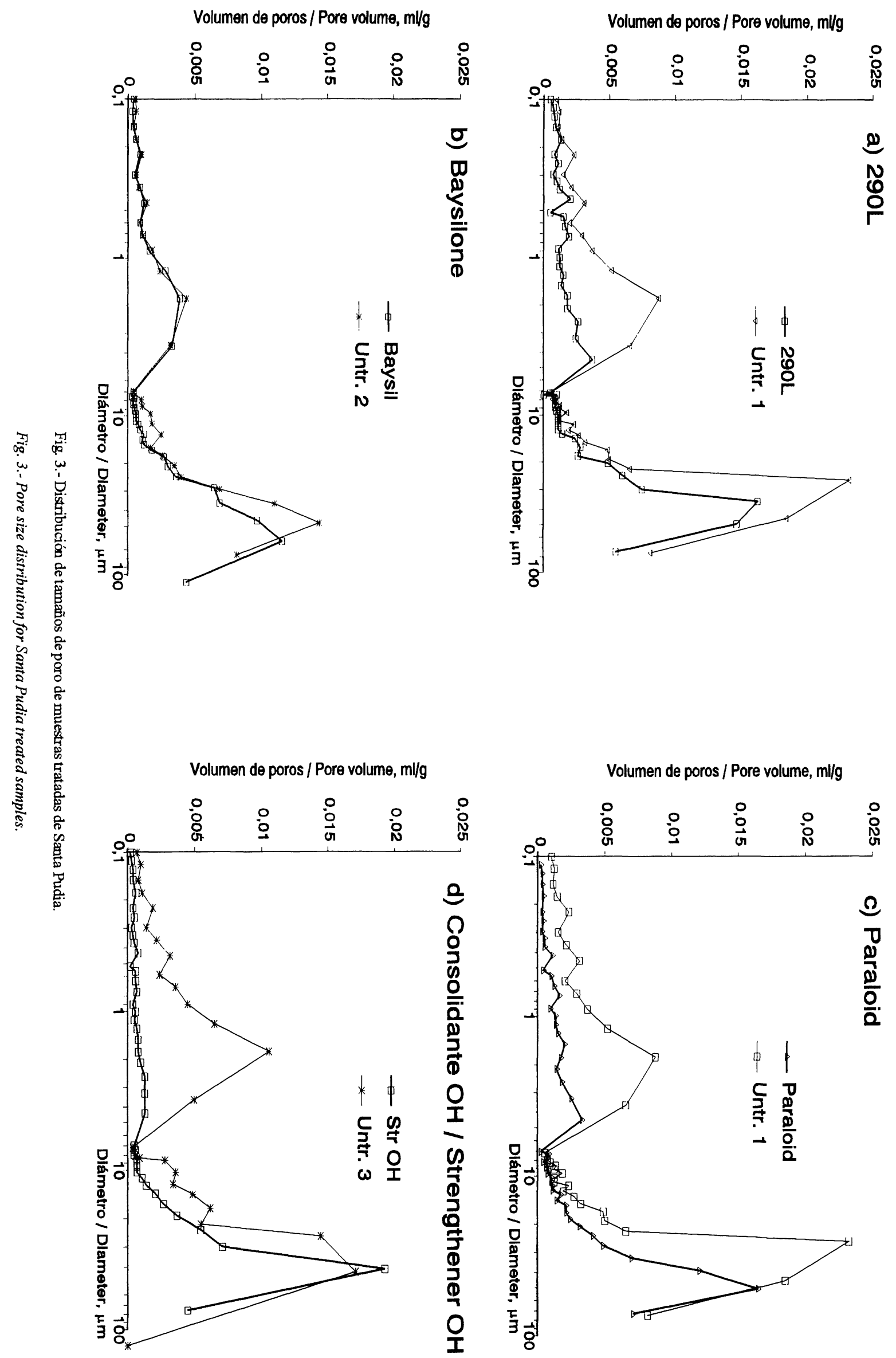
Datos obtenidos por porosimetría de intrusión de mercurio de muestras tratadas (Textural data obtained by mercury intrusion porosimetry for treated samples)

\begin{tabular}{|c|c|c|c|c|c|c|c|}
\hline \multirow{2}{*}{$\begin{array}{l}\text { producto } \\
\text { (product) }\end{array}$} & \multicolumn{3}{|c|}{$\begin{array}{c}\text { Porosidad al agua } \\
\text { Water porosity } \\
\text { (\%) }\end{array}$} & \multirow{2}{*}{$\begin{array}{c}\text { Porosidad de } \\
\text { intrusión de } \\
\mathrm{Hg} \\
\text { intrusion } \\
\text { porosity } \\
(\%)\end{array}$} & \multicolumn{2}{|c|}{$\begin{array}{c}\text { Volumen de intrusión } \\
\text { Intrusion volume } \\
\left(\mathrm{cm}^{3} \mathrm{~g}^{-1}\right)\end{array}$} & \multirow{2}{*}{$\begin{array}{c}\text { Mediana del } \\
\text { diámetro de } \\
\text { poros } \\
\text { (volumen) } \\
\text { Median pore } \\
\text { diameter } \\
\text { (volume) } \\
(\mu \mathrm{m})\end{array}$} \\
\hline & $\begin{array}{c}\text { Sin tratar } \\
\text { Untreat. }\end{array}$ & $\begin{array}{l}\text { Tratada } \\
\text { Treated }\end{array}$ & $\begin{array}{c}\text { Disminución media } \\
\text { debido al tratamiento } \\
\text { Average decrease } \\
\text { due to treatment }\end{array}$ & & $<10 \mu \mathrm{m}$ & $>10 \mu \mathrm{m}$ & \\
\hline Untr. I & 29,39 & - & - & 24,81 & 0,0505 & 0,0809 & 17,18 \\
\hline Tegosivin & 28,35 & 26,43 & 1,35 & 24,54 & 0,0420 & 0,0865 & 27,43 \\
\hline $290 L$ & 28,10 & 27,07 & 1,14 & 21,3 & 0,0435 & 0,0687 & 19,52 \\
\hline Paraloid & 28,11 & 26,18 & 0,73 & 19,4 & 0,0362 & 0,0687 & 23,10 \\
\hline Untr. 2 & 26,64 & - & - & 22,1 & 0,0529 & 0,0570 & 10,48 \\
\hline Tegovak. & 24,34 & - & 2,62 & 16,5 & 0,0388 & 0,0445 & 13,07 \\
\hline ARD & 24,97 & - & 0,80 & 17,8 & 0,0313 & 0,0581 & 22,54 \\
\hline Cons. OH & 24,94 & - & 3,55 & 13,56 & 0,0198 & 0,0480 & 26,42 \\
\hline BS28 & 25,17 & 23,1 & 1,28 & 20,73 & 0,0424 & 0,0618 & 16,46 \\
\hline Untr. 3 & 21,56 & - & - & 18,36 & 0,0290 & 0,0582 & 25,64 \\
\hline Baysilone & 21,15 & & 0,72 & 17,5 & 0,0270 & 0,0566 & 25,48 \\
\hline
\end{tabular}

TABLA 7 (TABLE 7)

Parámetros hídricos para muestras tratadas (Hygric parameters for treated samples)

\begin{tabular}{|c|c|c|c|c|c|}
\hline \multirow{3}{*}{$\begin{array}{l}\text { PRODUCTO DE } \\
\text { (TRATAMIENTO) } \\
\text { TREATMENT } \\
\text { (PRODUCT) }\end{array}$} & \multicolumn{5}{|c|}{ PARÁMETRO (PARAMETER) } \\
\hline & \multirow{2}{*}{$\begin{array}{c}\text { Capilaridad } \\
\text { (Capillarity) } \\
\text { Máxima agua } \\
\text { absorbida } \\
\text { Max. water } \\
\text { absorbed } \\
\left(\mathrm{g} \cdot \mathrm{cm}^{-2}\right)\end{array}$} & \multirow{2}{*}{$\begin{array}{c}\begin{array}{c}\text { Inmersión } \\
\text { (Immersion) }\end{array} \\
\text { Máxima agua } \\
\text { absorbida } \\
\text { Max. water } \\
\text { absorbed } \\
\left(\mathrm{mg} \cdot \mathrm{cm}^{-3}\right)\end{array}$} & \multirow{2}{*}{\begin{tabular}{|c|}
$\begin{array}{c}\text { Absorción de } \\
\text { gotas } \\
\text { (Drop absorption) }\end{array}$ \\
Tiempo de \\
absorción \\
Time of \\
absorption \\
(min) \\
\end{tabular}} & \multicolumn{2}{|c|}{$\begin{array}{l}\text { Evaporación } \\
\text { (Evaporation) }\end{array}$} \\
\hline & & & & $\begin{array}{l}\text { Valocidad de } \\
\text { evaporación } \\
\text { Velocity of } \\
\text { evaporation } \\
\left(\mathrm{mg} \cdot \mathrm{h}^{-1} \mathrm{~cm}^{2}\right)\end{array}$ & $\begin{array}{c}\text { Contenido crítico } \\
\text { de agua } \\
\text { Critical } \\
\text { water content } \\
\left(\mathrm{mg} \cdot \mathrm{cm}^{-3}\right)\end{array}$ \\
\hline Sin tratar/Untreated & $0,86 \pm 0,03$ & $197,2 \pm 1,6$ & $0,13 \pm 0,02$ & $4,03 \pm 0,39$ & $16 \pm 2$ \\
\hline Cons. $\mathrm{OH}$ & $0,34 \pm 0,02$ & $149,4 \pm 1,3$ & $62,5 \pm 7,5$ & $2,97 \pm 0,35$ & $24 \pm 3$ \\
\hline Tegovakon V & $0,77 \pm 0,03$ & $183,0 \pm 0,9$ & $13,9 \pm 8,8$ & $3,24 \pm 0,33$ & $32 \pm 2$ \\
\hline ARD 55.050 & $\S$ & $46,7 \pm 0,2 \#$ & $91,2 \pm 5,1$ & $2,66 \pm 0,38$ & $80 \pm 5$ \\
\hline Paraloid B72 & $\S$ & $103,4 \pm 0,7 \#$ & $79,5 \pm 3,9$ & $3,56 \pm 0,44$ & $56 \pm 3$ \\
\hline $290 L$ & $\S$ & $56,9 \pm 0,8 \#$ & $115,0 \pm 7,3$ & $3,53 \pm 0,19$ & $24 \pm 4$ \\
\hline BS28 & $\S$ & $70,0 \pm 1,3 \#$ & $111,4 \pm 4,8$ & $3,13 \pm 0,50$ & $56 \pm 3$ \\
\hline Baysilone & $\S$ & $64,6 \pm 1,5 \#$ & $106,2 \pm 7,2$ & $3,70 \pm 0,17$ & $64 \pm 5$ \\
\hline Tegosivin HL100 & $\S$ & $80,7 \pm 2,0 \#$ & $88,0 \pm 5,5$ & $3,93 \pm 0,39$ & $48 \pm 3$ \\
\hline
\end{tabular}

$\S$ Cantidad no apreciable / Not appreciable quantity \# Agua absorbida a los 8 días / Water absorbed at 8 days 
La absorción por inmersión disminuye grandemente con los productos hidrófugos y muy ligeramente con los consolidantes organosilícicos; el mejor comportamiento corresponde a ARD 55.050 y el peor a Paraloid B72. Consideraciones similares pueden hacerse por lo que respecta a la absorción de gotas.

Los datos de secado muestran que ninguno de los productos causa una disminución muy apreciable en la velocidad de evaporación; sin embargo, el valor del contenido crítico de agua aumenta, algunas veces de forma notable.

\subsection{Propiedades mecánicas}

Para evaluar el efecto consolidante de los productos se ha medido la dureza superficial en las probetas tratadas con los cuatro consolidantes. El incremento de dureza parece estar directamente relacionado con la cantidad de producto que permanece en la piedra, de forma que los mayores incrementos tienen lugar para Tegovakon V $(20 \%)$ y Consolidante $\mathrm{OH}$ (15\%) y los menores para ARD 55.050 (10\%) y Paraloid B72 (7\%).

\section{ENSAYOS DE ALTERACIÓN ACELERADA}

Se han realizado dos ensayos de alteración acelerada: de cristalización de sales con sulfato sódico y de ataque químico con atmósfera contaminada con $\mathrm{SO}_{2}$.

El ensayo de cristalización de sales ha estado formado por 75 ciclos de las siguientes características: $24 \mathrm{~h}$ de inmersión total en solución al $10 \%(\mathrm{p} / \mathrm{v})$ de sulfato sódico, $21 \mathrm{~h}$ de secado a $65^{\circ} \mathrm{C}$ y $3 \mathrm{~h}$ para enfriamiento y pesada. La temperatura de secado elegida es aceptable para los productos estudiados y el tiempo de secado suficiente para el tamaño de probeta.

El ensayo de ataque químico se ha llevado a cabo en una cámara de simulación ambiental durante 30 días con una atmósfera de 1000 ppm de $\mathrm{SO}_{2}$ y los siguientes ciclos: $24 \mathrm{~h}$ de aire seco a $40^{\circ} \mathrm{C}, 0,5 \mathrm{~h}$ de lluvia y $23,5 \mathrm{~h}$ de aire con $100 \%$ de $\mathrm{HR}$ a $40^{\circ} \mathrm{C}$.

Para ambos ensayos se han utilizado cinco muestras sin tratar y cuatro probetas por cada tratamiento. Al finalizar los ensayos se han medido algunas propiedades relacionadas con la absorción de agua; en las muestras sometidas al ensayo de ataque químico se ha analizado el contenido de sulfato de la superficie.

\subsection{Ensayo de cristalización de sales}

Los productos acrílicos tienen un comportamiento similar, desprendiéndose una capa superficial (Figura 4); este
Immersion water absorption greatly decreases with water repellent products and slightly with the two organosilicic consolidants; the best behaviour correspond to ARD 55.050 and the worse to Paraloid B72. Similar considerations can be made for the drop absorption data.

The evaporation data show that none of the products cause a very appreciable decrease in the velocity of evaporation; however, the value of critical water content increases sometimes notably.

\subsection{Mechanical properties}

With the aim of evaluating the consolidation effect of the studied products, surface hardness was measured on untreated material and on samples treated with the four consolidants. IIardness increase is directly related to the quantity of product that remains on the stone; so, the higher increases in hardness occur for Tegovakon $V(20 \%)$ and Strengthener $\mathrm{OH}$ (15\%) and less for ARD 55.050 (10\%) and Paraloid 372 (7\%).

\section{ACCELERATED WEATHERING TESTS}

Two accelerated weathering tests were carried out: a salt crystallization test with sodium sulphate and chemical attack with $\mathrm{SO}_{2}$ polluted atmosphere.

The salt crystallization test consisted of 75 cycles of the following characteristics: $24 \mathrm{~h}$ total immersion in $10 \%(w / v)$ sodium sulphate solution, $21 \mathrm{~h}$ drying at $65^{\circ} \mathrm{C}$ and $3 \mathrm{~h}$ for cooling and weighing. The selected drying temperature is acceptable for the products tested and the drying time is adequate for the sample size.

The chemical attack test was carried out in a simulation chamber during 30 days with an atmosphere of $1000 \mathrm{ppm}$ $\mathrm{SO}_{2}$ and the following cycles: $24 \mathrm{~h}$ dry air at $40^{\circ} \mathrm{C}, 0.5 \mathrm{~h}$ rain, and $23.5 \mathrm{~h} 100 \% \mathrm{RH}$ air at $40^{\circ} \mathrm{C}$.

For both tests, five untreated samples and four samples per treatment were tested. At the end of the tests, some properties related to water absorption were measured again; on the samples from the chemical attack test, surface sulphate content was analyzed too.

\subsection{Salt crystallization test}

The two acrylic products have a similar behaviour, loosening a surface layer (Figure 4); this process 
proceso tiene lugar después de 5-15 para las probetas tratadas con Paraloid B72 y después de 15-25 ciclos para las tratadas con ARD.

El resto de las muestras, incluidas las no tratadas, muestra un proceso de deterioro similar en todas ellas: desprendimiento de granos de la superficie.

Los consolidantes organosilícicos ralentizan el proceso de deterioro con respecto a las muestras no tratadas, que presentan una alteración muy importante después de 10 ciclos; las tratadas resisten 15 ciclos con Tegovakon y 15-25 ciclos con Consolidante $\mathrm{OH}$.

Las muestras tratadas con hidrófugos organosilícicos resisten un número de ciclos muy diferente: 40-50 BS28, 10-25 290L, y Baysilone y Tegosivin HL100 que llegan al final de los 75 ciclos sin alteración significativa.

La figura 5 muestra las curvas de evolución de peso de las probetas durante el ensayo, y la Tabla 8 muestra los valores de algunas características hídricas para las muestras que han completado los 75 ciclos sin alterarse.

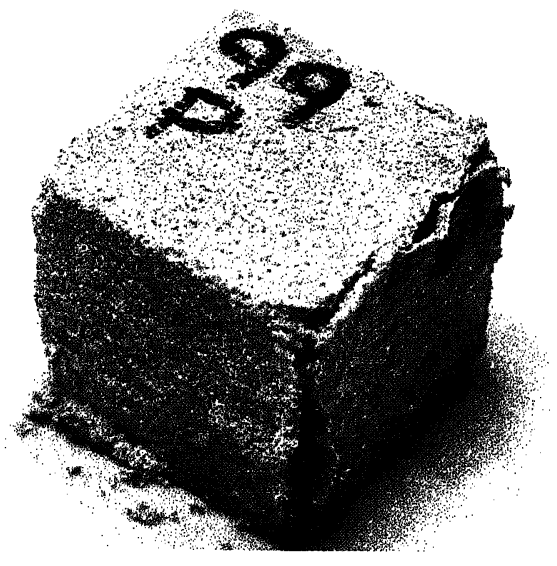

Fig. 4.- Muestra de Santa Pudia tratada con Palaroid B72 después de 10 ciclos del ensayo de cristalización de sales.

Fig. 4.- Santa Pudia sample treated Paraloid B72 after 10 cycles of salt crystallization test.

TABLA 8 (TABLE 8)

Parámetros hídricos de muestras tratadas tras el ensayo de cristalización de sales (Hygric parameters for treated samples after the salt crystallization test)

\begin{tabular}{|c|c|c|c|c|}
\hline \multirow{3}{*}{$\begin{array}{l}\text { PARÁMETRO } \\
\text { (PARAMETER) }\end{array}$} & \multicolumn{4}{|c|}{$\begin{array}{l}\text { PRODUCTO DE TRATAMIENTO } \\
\text { (TREATMENT PRODUCT) }\end{array}$} \\
\hline & \multicolumn{2}{|c|}{ Baysilone } & \multicolumn{2}{|c|}{ Tegosivin HL100 } \\
\hline & $\begin{array}{l}\text { Alterado } \\
\text { Weathered }\end{array}$ & $\begin{array}{c}\text { Sin alterar } \\
\text { Unweathered }\end{array}$ & $\begin{array}{c}\text { Alterado } \\
\text { Weathered }\end{array}$ & $\begin{array}{c}\text { Sin alterar } \\
\text { Unweathered }\end{array}$ \\
\hline $\begin{array}{l}\text { Capilaridad / Capillarity } \\
\text { Agua absorbida/Water absorbed } \\
\text { tras } 1 \text { día / at } 1 \text { day }\left(\mathrm{g} \mathrm{cm}^{-2}\right) \\
\text { tras } 7 \text { dias / at } 7 \text { days }\left(\mathrm{g} \mathrm{cm}^{2}\right)\end{array}$ & $\begin{array}{l}0,08 \pm 0,01 \\
0,11 \pm 0,01\end{array}$ & $\begin{array}{l}0 \\
0\end{array}$ & $\begin{array}{l}0,12 \pm 0,02 \\
0,15 \pm 0,03\end{array}$ & $\begin{array}{l}0 \\
0\end{array}$ \\
\hline 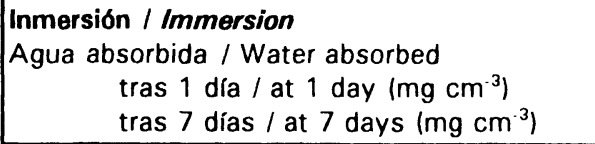 & $\begin{array}{l}28,2 \pm 1,3 \\
72,2 \pm 0,5\end{array}$ & $\begin{array}{l}13,4 \\
60,9\end{array}$ & $\begin{array}{l}29,2 \pm 3,1 \\
59,8 \pm 2,3\end{array}$ & $\begin{array}{l}18,9 \\
75,2\end{array}$ \\
\hline $\begin{array}{l}\text { Absorción de gotas / Drop absorption } \\
\text { Tiempo de absorción / Absorption time (min) }\end{array}$ & $106 \pm 21$ & $106,2 \pm 7,2$ & $133 \pm 20$ & $88,0 \pm 5,5$ \\
\hline
\end{tabular}




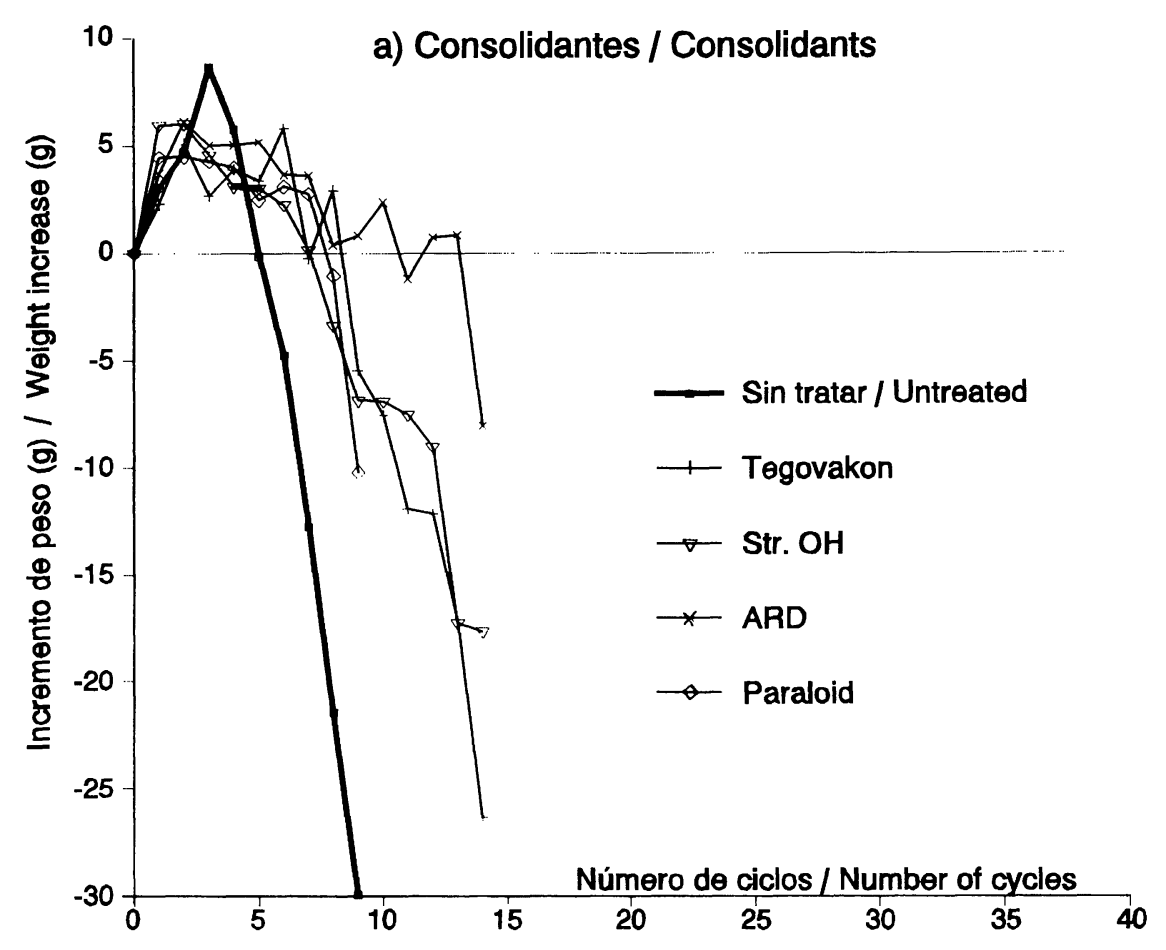

\section{b) Hidrófugos / Water repellents}

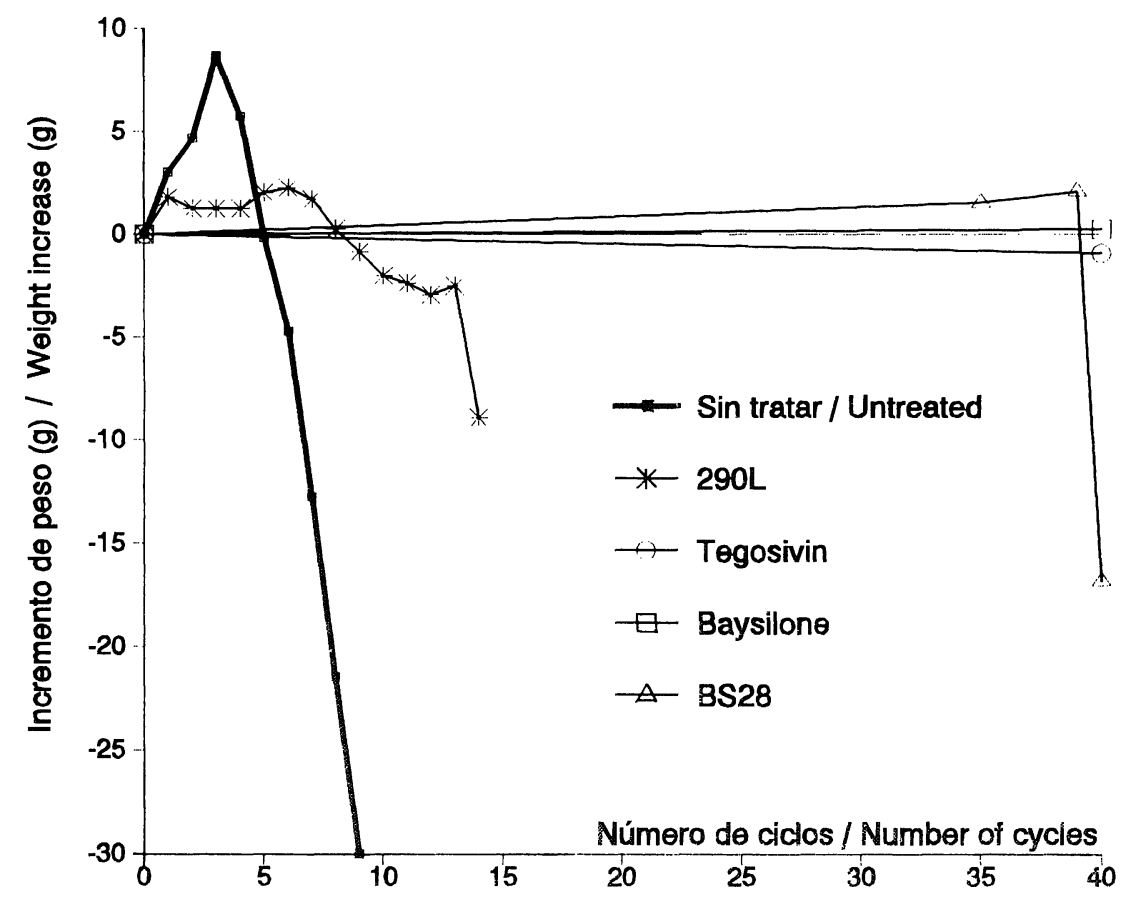

Fig. 5.- Evolución de peso de las muestras durante el ensayo de cristalización de sales.

Fig. S.- Weight evolution of the samples during the salt crystallization test. 


\subsection{Ensayo de ataque químico}

$\mathrm{El}$ ataque inducido en este ensayo se pone de manifiesto con la formación de sulfato cálcico en la superficie de las muestras. La formación de este compuesto, más soluble que el carbonato cálcico, produce la pérdida de peso de las muestras al disolverse en el agua de lluvia.

Las probetas tratadas con productos hidrófugos experimentan la misma formación de sulfato, pero debido a su hidrofugación las muestras no son mojadas tan fácilmente y los sulfatos formados no se disuelven en la misma medida; de esta forma, las pérdidas de peso son menores que en las muestras sin tratar.

En las muestras sin tratar se aprecia sólo la formación de eflorescencias pequeñas y localizadas. Un comportamiento similar aparece en las muestras tratadas con todos los productos, excepto 290L (Figura 6), que presentan escamas y disyunciones en algunos lados y aristas, y Tegosivin HL100, con disyunciones en vértices $\mathrm{y}$ aristas.

\subsection{Chemical attack test}

The attack induced in this test becomes apparent with the formation of calcium sulphate on the surface of the samples. The formation of this compound, more soluble than calcium carbonate, produces the loss of weight of the samples through dissolution on rain water.

The stones treated with hydrophobic products experiment the same formation of sulphate, but due to their water repellent character the samples are not wetted so easily and these sulphates do not dissolve on the same quantity; so, their losses of weight are smaller than those of untreated samples.

For the untreated samples it has to be noticed only the formation of very small and localized efflorescences. $A$ similar behaviour is presented by the samples treated with all the products except those treated with $290 \mathrm{~L}$ (Figure 6) which present blisters and disjunctions on some sides and edges, and with Tegosivin, with disjunctions on some edges and corners.

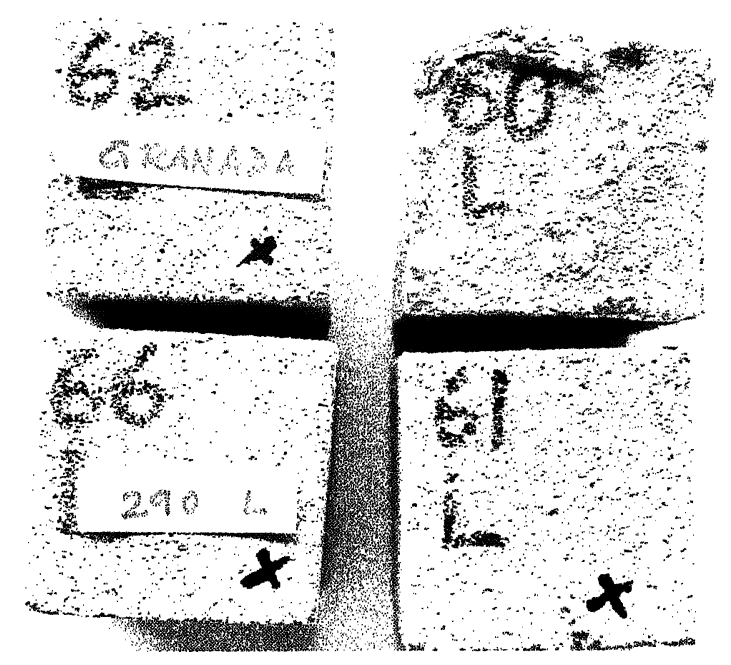

Fig. 6.- Muestras de Samta Pudia tratadas con 290I después del ensayo de ataque químico

Fig. 6. - Santa Pudia samples treated with $290 \mathrm{~L}$ after the chemical attack test.

La Tabla 9 recoge las propiedades hídricas medidas en las muestras después de la alteración, y el contenido de sulfatos de la superficie, que se ha analizado en una capa de $5 \mathrm{~mm}$ de espesor.
Table 9 shows some hygric properties measured on the samples after the weathering test, and the surface sulphate percentage, which was measured in a $5 \mathrm{~mm}$ thickness sheet. 
Parámetros hídricos y contenido de sulfatos de muestras tratadas

después del ensayo de ataque químico

(Hygric parameters for treated samples and surface sulphate content after the chemical attack test)

\begin{tabular}{|c|c|c|c|c|}
\hline \multirow{3}{*}{$\begin{array}{c}\text { PRODUCTO DE } \\
\text { TRATAMIENTO } \\
\text { (TREATMENT } \\
\text { PRODUCT) }\end{array}$} & \multicolumn{4}{|c|}{ PARÁMETRO (PARAMETER) } \\
\hline & $\begin{array}{c}\text { Capilaridad } \\
\text { Capillarity }\end{array}$ & $\begin{array}{l}\text { Inmersión } \\
\text { Immersion }\end{array}$ & $\begin{array}{c}\text { Absorción de gotas } \\
\text { Drop absorption }\end{array}$ & $\begin{array}{l}\text { Sulfato } \\
\text { Sulphate }\end{array}$ \\
\hline & $\begin{array}{c}\text { Agua absorbida } \\
\text { tras } 8 \text { días } \\
\text { Water absorbed at } \\
8 \text { days } \\
\left(\mathrm{g} \cdot \mathrm{cm}^{-2}\right)\end{array}$ & $\begin{array}{c}\text { Agua absorbida } \\
\text { tras } 8 \text { dias } \\
\text { Water absorbed at } \\
8 \text { days } \\
\left(\mathrm{mg} \cdot \mathrm{cm}^{-3}\right)\end{array}$ & $\begin{array}{l}\text { Tiempo de } \\
\text { absorción } \\
\text { Time of } \\
\text { absorption } \\
\text { (min) }\end{array}$ & $\begin{array}{c}\text { Contenido superficial } \\
\text { de sulfatos } \\
\text { Surface sulphate } \\
\text { content } \\
\left(\% \mathrm{SO}_{4}{ }^{2-}\right) \\
\end{array}$ \\
\hline Sin tratar ! Untreated & $1,25 \pm 0,12 \S$ & $207,3 \pm 1,9 \S$ & \# & $4,61 \pm 1,22$ \\
\hline Cons. OH & $1,15 \pm 0,08 \S$ & $189,5 \pm 2,1 \S$ & $\#$ & $4,45 \pm 0,11$ \\
\hline Tegovakon $\mathrm{V}$ & $1,12 \pm 0,04 \S$ & $195,2 \pm 0,8 \S$ & $\#$ & $2,82 \pm 0,60$ \\
\hline ARD 55.050 & $0,90 \pm 0,05$ & $165,4 \pm 1,8$ & $28,6 \pm 16,6$ & $3,22 \pm 0,98$ \\
\hline Paraloid B72 & $0,87 \pm 0,10$ & $174,3 \pm 2,3$ & $11,6 \pm 11,6$ & $4,53 \pm 1,60$ \\
\hline 290L & $0,28 \pm 0,02$ & $89,5 \pm 0,9$ & $6,2 \pm 5,9$ & $4,15 \pm 0,07$ \\
\hline BS28 & $0,14 \pm 0,02$ & $77,2 \pm 1,1$ & $13,5 \pm 11,1$ & $4,47 \pm 0,16$ \\
\hline Baysilone & $0,14 \pm 0,03$ & $77,8 \pm 0,7$ & $3,5 \pm 3,1$ & $4,26 \pm 0,91$ \\
\hline Tegosivin HL100 & $0,12 \pm 0,04$ & $89,9 \pm 0,8$ & $58,9 \pm 34,0$ & $4,85 \pm 0,30$ \\
\hline
\end{tabular}

§ Contenido máximo / Maximum content

Después del ensayo se ha medido la dureza superficial de las muestras tratadas y sin tratar, y los resultados revelan que el incremento de dureza obtenido con los consolidantes disminuye apreciablemente; de esta forma, se obtienen valores de 6-9\% para Tegovakon $\mathrm{V}$ y Consolidante $\mathrm{OH}$ y $2-4 \%$ para ARD y Paraloid B72.

\section{CONCLUSIONES}

\subsection{Comportamiento de los productos}

La Tabla 10 resume el comportamiento de los tratamientos. En la primera columna se indica la influencia de cada producto en las propiedades de la piedra. Para los consolidantes se ha considerado positivo incrementos de peso y de dureza superficial. Para los hidrófugos, la hidrorrepelencia, global y superficial, han sido los parámetros representativos. En ambos casos, una impregnación total se ha considerado positiva y una disminución acusada en la velocidad de secado negativa.

La segunda columna se basa en los resultados del ensayo de cristalización de sales; así, un producto se considera
After the chemical attack, the surface hardness of the untreated and consolidated samples was measured and the results reveal the hardness increments obtained with the use of consolidant products decreases substantially; so, these increments become only 6-9\% for Tegovakon and Strengthener $\mathrm{OH}$ and 2-4\% for ARD and Paraloid.

\section{CONCLUSIONS}

\subsection{Behaviour of the products}

Table 10 resumes the behaviour of the selected products on the Santa Pudia stone. In the first column the influence of each product on the properties of the stone is indicated. For the consolidants, weight and hardness increases have been considered as positive effects. For the hydrophobic products, the water repellent effect, global and superficial, have been the representative parameters. In both cases, a total impregnation has been considered as positive and a pronounced evaporation decrease as negative.

The second column is based on the results of the salt crystallization test; so, a product is considered very good 
Evaluación global de los productos de conservación para la piedra de Santa Pudia (Global evaluation of the conservation products on the Santa Pudia stone)

\begin{tabular}{||l|c|c|c||}
\hline \multicolumn{1}{|c|}{$\begin{array}{c}\text { PRODUCTO } \\
\text { (PRODUCT) }\end{array}$} & $\begin{array}{c}\text { Cambio de las propiedades de } \\
\text { la piedra debidos al tratamiento } \\
\text { Change of stone properties } \\
\text { due to treatment }\end{array}$ & $\begin{array}{c}\text { Comportamiento en el ensayo } \\
\text { de cristalización de sales } \\
\text { Behaviour on salt } \\
\text { crystallization test }\end{array}$ & $\begin{array}{c}\text { Comportamiento en el } \\
\text { ensayo de ataque químico } \\
\text { Behaviour on } \\
\text { chemical attack test }\end{array}$ \\
\hline $\begin{array}{l}\text { Consolidante } \mathrm{OH} \\
\text { Strengthener } \mathrm{OH}\end{array}$ & ++ & 0 & 0 \\
Tegovakon V & ++ & 0 & 0 \\
ARD 55.050 & + & - & ++ \\
Paraloid B72 & + & - & - \\
$290 \mathrm{~L}$ & ++ & ++ & + \\
BS28 & ++ & ++ & + \\
Baysilone LV & ++ & ++ & - \\
Tegosivin HL100 & + & + & + \\
\hline
\end{tabular}

CÓDIGO/CODE: + + muy bueno/very good; + bueno/good; o nulo/null; - negativo/negative

muy bueno cuando el deterioro es prácticamente inexistente, bueno si las muestras resisten un número considerable de ciclos, nulo cuando su comportamiento es similar a las muestras sin tratar y negativo si el deterioro es igual o más acusado que en las muestras sin tratar.

La tercera columna corresponde al ensayo de ataque químico con $\mathrm{SO}_{2}$; si la alteración es nula o escasa el producto se considera muy bueno o bueno, respectivamente; para grados de deterioro similares al de las muestras no tratadas el efecto se considera nulo y para deterioros superiores, negativo.

Los consolidantes organosilícicos presentan un buen efecto consolidante, pero dado que estos productos no tienen propiedades hidrófugas, no proporcionan protección en los ensayos de alteración; estas probetas muestran un grado de deterioro similar a las no tratadas.

Los dos productos acrílicos tienen, en general, un efecto negativo, además ARD 55.050 produce un acusado descenso en la velocidad de secado. Es importante señalar la baja profundidad de penetración de Paraloid B72, que es la causa del mal comportamiento de este producto. Estos productos pierden sus medianas características hidrófugas después de un largo periodo de contacto con el agua, de forma que la solución de sulfato sódico penetra y tiene lugar la cristalización de la sal detrás de la capa tratada, provocando la disgregación del material y la caída de la capa tratada. when the deterioration was practically inexistent, good if the samples have resisted a considerable number of cycles, null when their behaviour were similar to the untreated ones and negative if the deterioration was marked or more serious than that of the untreated samples.

The third column corresponds to the chemical attack test with $\mathrm{SO}_{2}$; if the deterioration was null or scarce, the product has been considered as very good or good, respectively; for deterioration degrees similar to those of the untreated samples, their effect was considered as null, and for major deterioration as negative.

The organosilicic consolidants present a good consolidant effect, but since these products do not have hydrophobic properties, they do not provide any protection on the deterioration tests; these samples present a similar weathering degree as the untreated ones.

The two acrylic products have, in general, a negative effect, moreover ARD 55.050 causes a great evaporation rate decrease. It is important to point out the low depth of penetration of Paraloid which is the cause of the poor behaviour of this product. These products lose their poor hydrophobic characteristics after a long period of contact with water; so, salt crystallization occurs behind the treated surface, causing the material dissagregation with loosening of this treated layer. 
En general, los hidrófugos organosilícicos ofrecen los mejores resultados en los ensayos de alteración, y sus características hidrofóbicas afectan sólo en la superficie; entre ellos puede destacarse BS28. Estos productos no originan una gran disminución de la velocidad de secado, por lo que pueden considerarse buenos en este aspecto. Todos los productos, excepto 290L, resisten bien el ensayo de cristalización de sales, manteniendo su hidrofobicidad. En el ensayo de ataque con $\mathrm{SO}_{2}$, el mejor comportamiento es el de BS28, siendo Tegosivin HL100 el producto con un efecto más negativo; sin embargo, éste es el único que mantiene la hidrorrepelencia superficial.

\subsection{Propuestas de conservación}

De acuerdo con los resultados obtenidos en este trabajo, podría proponerse la aplicación de algunos tratamientos a determinadas zonas de la Catedral de Granada después de la limpieza y de algunas intervenciones estructurales.

Para la piedra localizada en zonas del edificio sometidas a altos niveles de humedad, donde la cristalización de sales es el mecanismo de alteración más importante, los mejores resultados se obtendrían con Baysilone LV y Tegosivin HL 100, siempre que no tenga lugar el ataque químico.

Para la piedra situada en las zonas superiores del monumento y sometida principalmente a ataque por $\mathrm{SO}_{2}$, ARD $55.050 \mathrm{y}$, especialmente, BS28, podrían ser los productos con mejor resistencia.

Si se prefiere la aplicación de un sólo producto, o si tienen lugar los dos mecanismos de alteración, la elección apropiada podría ser BS28, que ha mostrado el mejor comportamiento en general.

\section{AGRADECIMIENTOS}

Este trabajo se ha realizado con una subvención de DICYT. Agradecemos a J.L. Pérez Bernal, del Dpto. de Química Analítica, la obtención de los datos de porosimetría.
In general, organosilicic water repellent products give the best results on the weathering processes and their hydrophobic properties were only affected on the surface; BS28 can be pointed out for its good behaviour. These products do not cause a pronounced decrease on the rate of evaporation, therefore they can be considered as very good treatments on this aspect. All the products, except 290L, resisted well the salt crystallization test, remaining its hydrophobicity. On the $\mathrm{SO}_{2}$ chemical attack test the best behaviour was that of BS28, Tegosivin HL100 being the product which has a higher negative effect; however, only Tegosivin keeps up the surface water repellency.

\subsection{Conservation proposals}

According to the results obtained in this work, after stone cleaning and preliminary structural interventions (reinforcements, replacement of oxidized iron buds, etc), the application of several treatment products to some zones of the Granada Cathedral could be proposed.

For stones located in lower zones of the building or submitted to high humidity levels where salt crystallization is the most important process, the best results would be obtained with Baysilone LV and Tegosivin HL100, provided that no chemical attack takes place.

For the stones located in upper zones of the monument and submitted mainly to $\mathrm{SO}_{2}$ attack, ARD 55.050 and fundamentally BS28 would be the products which would show better resistance.

To conclude, if the application of only one product is preferred or the two weathering processes occur, the appropiate choice seems to be BS28, which has shown the best global behaviour.

\section{ACKNOWLEDGEMENTS}

This work has been realized with a DICYT subvention. We greatly appreciate the colaboration of Mr. J. L. Pérez Bernal, Dpt. of Analytical Chemistry, for the obtention of the porosimetric data.

Fabricantes de los tratamientos / Manufacturers of products

ARD 55.050: ARD F.lli Raccanello SpA, Strada 1, Zona Industriale no. 13, 35129 Padua, Italy.

Paraloid B72: Rohm \& Haas Company, Philadelphia, PA 19105, USA.

Tegosivin HL100 and Tegovakon V: Th. Goldschmidt AG, Goldschmidtstrasse 100, 4300 Essen, Germany.

Stone Strengthener OH, BS28 and 290L: Wacker-Chemie GmbH, 8 München 22, Postfach, Germany.

Baysilone LV: Bayer AG, 5090 Leverkusen, Germany 


\section{BIBLIOGRAFIA}

(1) ALCALDE, M., MARTIN, L., BELLO, M.A. and MARTIN, A.: "Macroscopical morphology of deterioration of the stone used in the Cathedral Whole of Granada (Spain)", Materiales de Construcción, 42(226). (1992). pp. 27-48.

(2) INSTITUTO NACIONAL DE METEOROLOGIA: “Atlas climático de España”, Ed. I.N.M., Madrid, (1983).

(3) INSTITUTO NACIONAL DE METEOROLOGIA: “Climatología de España y Portugal”, Ed. I.N.M., Madrid, (1983).

(4) BERZOSA, J. and MARTIN, A.: “Análisis rápido de materiales calizos y silíceos.I. Determinación de sílice”, Ensayos $e$ Investigación, 1(3). (1966). pp. 12-18.

(5) BERZOSA, J. and MARTIN, A.: “Análisis rápido de materiales calizos y silíceos.II. Determinación de aluminio, hierro y titanio", Ensayos e Investigación, 1(4). (1966). pp. 12-24.

(6) BERZOSA, J. and MARTIN, A.: “Análisis rápido de materiales calizos y silíceos.III. Determinación de calcio, magnesio, sodio y potasio", Ensayos e Investigación, 1(5). (1966). pp. 16-29.

(7) ASTM C170-76: "Standard test method for compressive strength of natural building stone".

(8) RILEM COMISSION 25-PEM: "Protection et érosion des monuments", Ed. Bordas-I)unod, Paris, (1978).

(9) VALE, J., CORTES, V. and MARTIN, A.: "Ensayos de materiales en atmósferas simuladas. II. Diseño de un sistema de simulación", Materiales de Construcción, 190-191. (1983). pp. 53-68.

(10) VALE, J. and MARTIN, A.: "Deterioration of a sandstone in simulated atmospheres", Durability of Building Materials, 3. (1986). pp. 183-196.

(11) MARTIN, L., BELLO, M.A. and MARTIN, A.: "Stone characterization and alteration processes of the Cathedral of Granada (Spain)", Proc. 7th Int. Cong. on Deterioration and Conservation of Stone, Lisboa (Portugal), III. (1992). PP. 1499-1505.

(12) MARTIN, L., BELLO, M.A. and MARTIN, A.: "Alteration mechanisms on the stones of the Cathedral of Granada (Spain)", Materiales de Construcción, 43(229). (1993). pp. 25-33.

(13) SKIOTIS, D., PARADELLIS, T. and KATSELIS, V.: "Catalytic oxidation of $\mathrm{SO}_{2}$ on marble surfaces', Proc. 3rd Int. Cong. on the Deterioration and Conservation of Stones, Venezia. (1979). pp. 35-41.

(14) BUFALINI M.: "Oxidation of sulphur dioxide in polluted atmospheres- A review”, Environ. Sci. Technol., 5. (1971). pp. 685693.

(15) YOCOM J.E.: “Air pollution damage to buildings on the Acropolis”, J.Air Pollution Control Assoc., 29. (1979). pp. 33-40.

(16) LEWIN, S.Z. and WHEELER, G.E.: "Alkoxysilane chemistry and stone conservation", Proc. 5th Int. Cong. on Deterioration and Conservation of Stone, Lausanne. (1985). pp. 831-844.

(17) CHAROLA, A.E., WHEELER, G.E. and FREUND, G.: "The influence of relative humidity in the polymerization of methyltrimetoxilane", Adhesives and Consolidants, Paris. (1984). pp. 177-181.

(18) PAULY, J.P.: "Qualité d'un traitment et teneur en eau", Proc. 5th Int. Cong. on Deterioration and Conservation of Stone, Lausanne. (1985). pp. 817-829. 